\title{
Development of Sparkol Vidoescribe Learning Media to Increase The Students Learning Motivation in Fiqh Subject
}

\author{
Siti Fatimah, Maemunah Sa'diyah \\ Pendidikan Agama Islam Universitas Ibn Khaldun Bogor \\ E-mail address: fatimahntdgs@gmail.com
}

\begin{abstract}
This research aims define the expediency of Sparkol learning media Videoscribe, and see the learning media Sparkol Videoscribe affects the student motivation in class X. This research uses Research and Development. The research data shows that the media expert is equal to $91.18 \%$ while subject experts were $80.556 \%$. At the testing stage, individual trials shows the number $86 \%$ while for testing to small group pointed at $98 \%$. The final result of the test, the validation test show marks the sig $0.00<0.05$ with differences in results of class control at $74.31 \%$ and $82.06 \%$ at the experimental class. In conclusion, the development learning media Sparkol Videoscribe as a Fiqh teaching material is worthy of use to increase the motivation in student learning.
\end{abstract}

Keywords: Sparkol Videoscribe, Learning Motivation, Fiqh

Islam studies is education that are able to explore the positive ability of people and suppress the poor ability of people, which is actually be the main task of the academics to its application (Sa'diyah, M, 2019: 5). The quality of education defines the quality of human resources, that is why education needs to be given from birth to be able to build someone's knowledge, intelligence, and noble character so that they have a good personality and can behave well (Utami, PRA, et al, 2018: 26). The improvement on the competency of Islamic education resources, namely teachers of Pendidikan Agama Islam (PAI) (Islamic Religious Education) should be conducted. This effort is aimed so that Islam educational resources in our country are competitive and as well as comprehend the learning patterns in the era of industrial revolution 4.0.

Learning is a knowledge transfer activity deliberately designed by a teacher by using various strategies and learning media, in order to make it easier for students to achieve their learning goals. A good teaching and learning process will affect learning objectives and can also improve student learning outcomes (Sahronih, S, et al, 2020: 1). The use of technology in the learning process in classes is expected able to provide solutions to cope with the classes learning (Syakur, A, et al, 2020: 476).
According to Lin Ming-Hun, et al (2017: 3554) the design of teaching activities and the use of flexible applications by digital learning become a major issue in integrated education within the information technologies today.

According Qolbi, et al (2019: 52) the consideration of study facilities also needs to be optimized, this optimization can be done by the teacher such as by developing the learning media. According to Ahmad Fujiyanto, et al (2016: 844) the function media learning is not only efficient in learning itself, but also able to provide the abstract exoeriences becomes more manifested. The quality learning media is able to increase student motivation, efficient and flexible, and as well as stimulates and attracts student attention so that there is feedback and encourages students to apply it correctly in everyday life (Enita, P, et al, 2019: 25).

One of the factors that determine the success in the student learning process is motivation of learning itaelf (Lumbantobing, PA, 2020: 556). Adam \& Muhammad Taufik (2015: 89) mentioned that motivation is stimulation that encourages students to get involved carry out learning activities in order to learning objectives are achieved. In other words, motivation is a form of encouragement that can involve students in learning activities. 
Usually a teacher shall comprehends some matters such as that when students need to be motivated for the learning process, and how the learning process should enjoyable, reduce anxiety in students and enhance students' creativity (Fitri, Y, 2020: 200). When students have high learning motivation, teaching and learning activities tend to increase in the sense of learning that leads to be active and students will really follow the teaching and learning process so that the expected learning objectives can be achieved (Pohan, et al, 2020: 534).

Self confidence and their learning motivation greatly affect student learning outcomes (Radyuli, P, et al, 2020: 217). When individuals realize that environment can have a negative effect on the learning process they are on, they begin to question their own abilities. So that in this case they are looking for a way out and unconsciously motivation to learn will be formed (Chang, IY, \& Chang, WY, 2012: 284).

The motivator who is very influential in creating an active learning atmosphere in the classroom when learning PAI is the teacher, learning will be successful if the teacher has step-forward thinking and creativity in learning activities (Lutfiah \& Maemunah Sa'diyah, 2019: 497). Students who are highly motivated will tend to have high personal responsibility, willing to take risks, have a study plan, diligent, determined, actively learn, do not feeling self-complacent, and always try to achieve the best results (Bakar, R, 2014: 723).

The subject of PAI (red; Pendidikan Agama Islam/Islamic Education) is inseparable from fiqh material, from elementary to high school, fiqh material is always in PAI lessons. Fiqh material is very important in the discussion of Islamic education subjects, because not many students at home are devoted to learning Islamic education material. So that in formal education, the procedures for worship must be taught to students from an early age. General education and religious education must be balanced to be learned by a student, so that their application in daily life is in accordance with Islamic teachings.

However, as the writer has noticed in the field is that there are still many Fiqh teachers at Madrasah Aliyah in the teaching process using conventional methods. This conventional method is considered as a traditional way of delivering material which is centered only on the teacher. Based on the observations conducted by researchers on February 21-26, 2020 class X at MAN 1 Bogor City in the Fiqh subject, researchers noticed that there were still many students who were less motivated in learning activities, many students who were still chatting and did not pay attention to the teacher when explaining.

Due to the lack of student attention when the fiqh subject teacher explains verbally, besides the teaching system using textbooks can also use video media, one of which is Sparkol media, videoscribe. The latest findings in this study is the development of Sparkol Videoscribe learning media on fiqh subchapters such as Riba, Bank and Insurance to increase students' motivation.

Furthermore, in previous research regarding the use of Sparkol Videoscribe media on student interest in learning is Wulandari's thesis (2016), it was concluded that there was an increase in learning interest in classes using Sparkol Videoscribe media. This also happened in the research of Maulina, $U$, et al. (2019), which concluded that there was a positive influence in overcoming the speaking skills of students in an experimental group who were treated using Sparkol Videoscribe. Based on the research results of Aryuntini, N, et al (2018), it was concluded that there was an increase in students' ability to write descriptive text before and after using Sparkol Videoscribe media. Meanwhile, in the research of Sofyan, A., et al, (2019) it can be concluded that learning media using Sparkol Videoscribe software in science subject able to increase student interest in the learning process.

The purpose of this study is to determine the expediency of Sparkol Videoscribe learning media to increase the students motivation towards fiqh learning in the sub-chapter of material on Riba, Bank and Insurance with an assessment consisting of media experts and subject experts as well as the appropriateness of student assessments in student motivation, defining the feasibility of Sparkol Videoscribe to increase student motivation to learn fiqh, and to be able to determine the effect of Sparkol Videoscribe to increase student motivation to learn fiqh. 


\section{METHOD}

\section{Research Design}

The method used in this research is research and development (R\&D). In this study, the writer used research and development steps with ASSURE model design (Analyze Learner, State Objectives, Select Methonds, Media and Materia, Utilize Media and Material, Require Learner Participation, Evaluate and Revise).

However, due to limited time in carrying out the research, the writer using research stages that have been modified by Nur Hannah (2016). In his thesis, he shows seven stages of the ASSURE modification model with Sugiyono's R\&D, consisting (1) Preliminary Study, (2) Learning Analysis, (3) Determining Objectives, (4) Choosing Technology, Methods, Media and Materials, (5) Developing Learning Media, (6) Evaluation and (7) Utilization of Fiqh Learning Media in Increasing Student Motivation.

This research took place in MAN 1 Bogor City, involving 70 students in class $\mathrm{X}$. The research subjects were divided into two groups, class $\mathrm{X}$ MIPA 1 as many as 35 people as the control class and class X MIPA 3 as many as 35 people as the experimental class. To measure student motivation before testing, the writer uses pre-test for both classes. Meanwhile, to measure the increasing motivation in students after testing activities are carried out post-test in both classes.

This study uses a research design quasiexperimental under the type of non-equavalent control group prettets-posttest which is using a class with the same conditions in the unit level of the education, which in this case is class 10 . Both classes are given pre-test before the test begins, to find out how much motivation they have towards Fiqh subjects. Meanwhile, to measure student motivation after testing the writer uses posttest given after the learning activity is complete with a difference by the experimental class using learning media Sparkol Videoscribe while the control class uses conventional learning methods.

\section{Research Instruments}

This research was conducted on the subject of Figh with its sub-chapters Riba, Bank and Insurance in class $\mathrm{X}$, using several research instruments in the forms of (1) the instrument appropriateness of Sparkol Videoscribe media in the fiqh subject in the form of a questionnaire sheet consisting of a validation tests of media expert and subject expert, (2) an instrument for measuring student's studying motivation uses a questionnaire based on 8 indicators, consisted active in doing assignments, resilient or not easily discouraged when encounter problems that are difficult to work on, have an interest in various kinds of problems, prefer to work individually, have creativity, so they do not like things that are repeated, stick to their stance or with their own beliefs, and able to find and solve problem (Sardiman, 2016: 83).

On the properness of learning media Sparkol Videoscribe, The research instrument used 2 expert lecturers consisting of media experts and subject experts according to the BSNP assessment standard. To find out the properness of the Sparkol Videoscribe to determine the maximum score of the validator by adding up the scores obtained from the validation assessment sheet on the qualitative values. After doing the addition on the validator's assessment sheet, then the next step is to determine the percentage result with the formulation of the score interpretation criteria adjusted to the likert scale.

\section{Data Collection Technique}

Data collection technique is a way which is used by researchers to gather various information related to the problem in research. This technique is used to produce valid and reliable data. In this case, the writer uses research instruments in data collection techniques in the form of interviews, observations, distributing questionnaires as affirmation, as well as documentary studies to strengthen the archives of the schools studied.

According to Suharsimi Arikunto (2017: 44) interview is a method used by someone to get information from respondents using unilateral questions and answers. On the other hand, observation according to Amir Hamza (2019: 
123) is a data collection technique by directly observing a situation or circumstances of a research subject. This observation activity may include student behavior, attitudes, environmental set and various other aspects that are carried out if the observed respondents are not too large. Nana Syaodih Sukmadinata (2017: 219) explains that a questionnaire is a way to collect data indirectly with respondents. Meanwhile, the documentary studies according to Nana Syaodih Sukmadinata (2017: 221 ), is a way of collecting data by collecting and analyzing documents, both written, image and electronic documents.

The questionnaire used by the writer consisted of media expert questionnaire, subject expert validity test questionnaire, assessment questionnaires by students both for individual trials and small group trials. In addition, there is a questionnaire used to measure student learning motivation. The scoring used in this questionnaire adopting Likert scale that possess gradient colors ranges from the very positive to very negative (Sugiyono, 2017: 135).

\section{Data Analysis Technique}

The data analysis technique used by the writer is divided into an analysis of the expediency of learning media, and data analysis of learning motivation questionnaires. In analyzing the results of properness of learning media Sparkol Videoscribe, this analysis process tries to see the product appropriateness of the validation questionnaire given to the validator to assess the feasibility of the product using a formula likert scale as follows:

$$
P k=\frac{S}{N} \times 100 \%
$$

Explanations:

(Anas Sudijono, 2015: 43)

$\mathrm{Pk}=$ Feasibility scale category value

$\mathrm{S}=$ Total score obtained

$\mathrm{N}=$ Total ideal score

From the calculation results and the value found, the next step is to see the qualification value of the scale of the achievement level.
Table 1. Score Interpretation Criteria

$\begin{array}{lll}\text { Presentase (\%) } & \text { Qualification } & \begin{array}{l}\text { Eligibility } \\ \text { Criteria }\end{array} \\ 80 \%-100 \% & \text { Very good } & \begin{array}{l}\text { Revision is not } \\ \text { required / } \\ \text { good }\end{array} \\ & \text { Good } & \begin{array}{l}\text { Revision is not } \\ \text { required / } \\ \text { good }\end{array} \\ & \text { Fair } & \begin{array}{l}\text { Revision is } \\ \text { required / } \\ \text { Deficient }\end{array} \\ & & \begin{array}{l}\text { Revision is } \\ \text { required / } \\ \text { Deficient }\end{array} \\ & \text { Deficient } & \text { Revision is } \\ & & \text { required / } \\ & \text { Deficient }\end{array}$

(Riduwan, 2012: 15)

The data analysis on the achievement of student learning motivation is used to determine the increase in student motivation using Sparkol Videoscribe at the fiqh lesson by using the program SPSS 25 for Windows. The analyzed data is obtained from the observation of student learning motivation in the experimental class and the control class using the paired T-test.

The T-test used is Paired Samples Test to test the mean comparison of paired data, namely data prestest and posttest the student motivation and T-test by independent samples test to mean the comparison of unpaired data which is posttest motivation to learn students with assistance IBM SPSS Statistics version 25 for Windows.

\section{Research Findings and Study Results}

Media products Sparkol Videoscribe has several parts in it, including (1) the first minutes has cover sub-chapter material regarding Riba, Bank, and Insurances, educational unit level, and the identity of the instructor media maker Sparkol Videoscribe as well as its learning objectives, (2) explanation of the material Riba, Bank and Insurance and as well as questions to stimulate students to be active in learning activities and to 
motivate students to learn, (3) at the last minutes there is the identity of the researcher and thanks to the lecturer who has guided in making the learning media.

The feasibility of learning media Sparkol Videoscribe In the subject of fiqh, the subject of Riba, Bank and Insurance is validated by two experts, namely a media expert and a subject expert.

Table 2. Validator names

\begin{tabular}{|c|c|c|c|}
\hline No. & $\begin{array}{l}\text { Validator } \\
\text { Name }\end{array}$ & $\begin{array}{l}\text { Validator } \\
\text { Field }\end{array}$ & Information \\
\hline 1. & $\begin{array}{l}\text { Muhammad } \\
\text { Yusuf } \\
\text { Iskandar, } \\
\text { M.Pd. }\end{array}$ & $\begin{array}{l}\text { Media } \\
\text { Expert }\end{array}$ & $\begin{array}{l}\text { Lecturer of } \\
\text { Teknologi } \\
\text { Pendidikan dan } \\
\text { Pengembangan } \\
\text { UIKA Bogor. }\end{array}$ \\
\hline 2. & $\begin{array}{l}\text { Dr. } \\
\text { Maemunah } \\
\text { Sa'diyah, } \\
\text { M.Ag. }\end{array}$ & $\begin{array}{l}\text { Subject } \\
\text { Expert }\end{array}$ & $\begin{array}{l}\text { Lecturer and } \\
\text { Chief PAI UIKA } \\
\text { Bogor study } \\
\text { program }\end{array}$ \\
\hline
\end{tabular}

The calculation results of instrument validation from media experts and subject experts are categorized according to likert scale criteria, as follows:

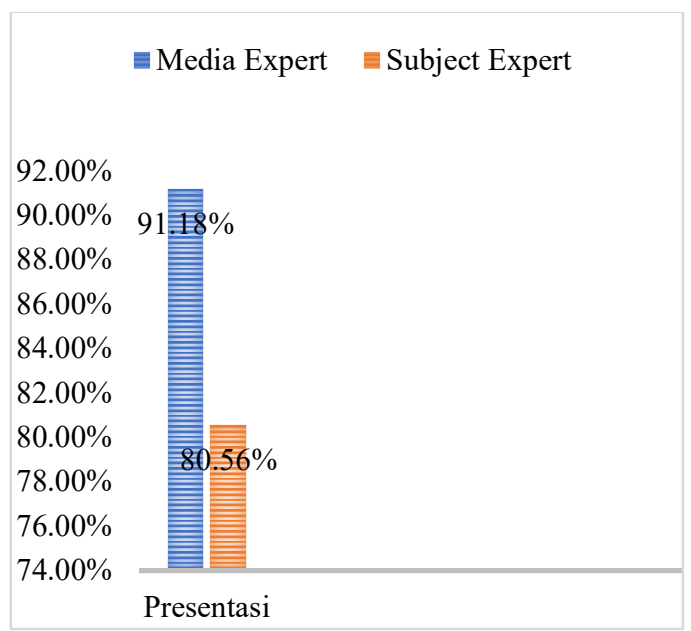

Fig. 1. Media feasibility validation results

Taking the results of student responses to student self-assessment is carried out on individual or individual tests, and small group tests.

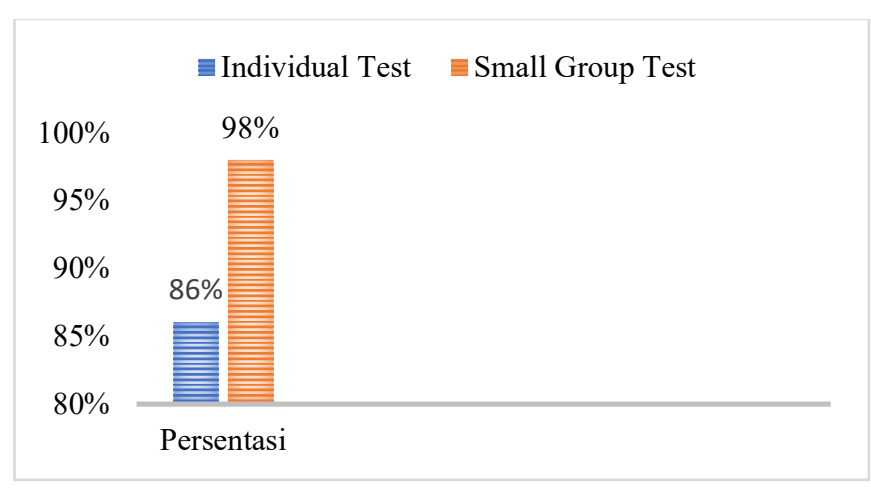

\section{Fig. 2. Results of Student Self-Assessment Responses}

Furthermore, for the use of Sparkol Videoscribe on learning fiqh, validation test is carried out by comparing the control class and the experimental class. In the following validation test, first the data analysis was carried out by conducting the prerequisite test, which are the normality test and the homogeneity test. The normality test is conducted to determine whether the sample is normally distributed or not. While the homogeneity test is a of variety of questions and is used to determine whether the two sample groups have the same or different variants (Asep Saepul Hamd i and E. Bahruddin, 2014: 122).

During the normality test and test homogeneity, the writer uses the application SPSS 25 for Windows. The normality test is carried out using the formula Tests of Normality Kolmogorov-Smirnov with a decision:

Ho is rejected, if the probability ( $\mathrm{sig})>0$, 05 (samples are normally distributed)

Ho is accepted, if the probability (sig) $<0.05$ (samples are not normally distributed)

The results of these normality test results and homogeneity test are obtained from the results of the experimental class and class control. Based on the calculations using the SPSS 25 application regarding the normality test in the class control and the experimental class, then the results obtained is experiment pretest: probability ( $\mathrm{sig}$ ) $0.071>0.05$ so that $\mathrm{Ho}$ is rejected, then the data is normally distributed and post-test experiment: probability 
(sig) $0.200>0.05$ so that Ho is rejected, then the data is normally distributed, while for class control pretest obtained: Probability ( $\mathrm{sig}$ ) $0.200>0.05$ so that Ho is rejected, then the data is normally distributed and class control post-test: Probability (sig) $0.200>0.05$ so that Ho is rejected, then the data is normally distributed.

Based on the results of the homogeneity test on table 4, the results obtained (sig) base on mean in the amount of $0.487>$ from 0,05 . Then it can be concluded that the data is homogeneous or with similar variants. Learning media product Sparkol Videoscribe has several parts in it, including (1) the first minutes is contained subchapters of materials regarding Riba, Bank, and
Insurances, educational unit level, and the identity of the instructor media maker Sparkol Videoscribe as well as the learning objectives, (2) explanation of the material Riba, Bank and Insurance as well as questions to stimulate students to be active in learning activities and to motivate students in learning, (3) at the last minutes contains the identity of the researcher and thanked to the lecturer who has guided in the making the learning media.

Based on the results of the normality test and homogeneity test, the next step is regarding the results of assessing student learning motivation using learning media Sparkol Videoscribe in the fiqh subject.

Table 3. Description of student's Learning Motivation Statistics

\begin{tabular}{|l|l|l|l|l|l|}
\hline Descriptive Statistics & N & Min & Max & Mean & Std. Deviation \\
\hline Pre-Test Experiment class & 35 & 55 & 94 & 71.34 & 10.126 \\
\hline Post-Test Experiment class & 35 & 66 & 95 & 82.06 & 6.131 \\
\hline Pre-test Control class & 35 & 59 & 86 & 69.51 & 7.027 \\
\hline Post-Test Control class & 35 & 61 & 88 & 74.31 & 7.066 \\
\hline Valid N (listwise) & 35 & & & & \\
\hline
\end{tabular}

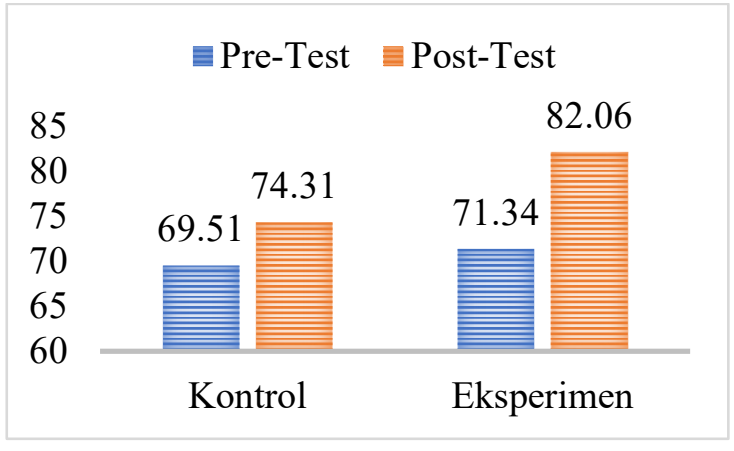

Fig. 3. Result of Pre-Test and Average Rating Post-Test in Control Class and Experiment Class
The above data shows that there is an average difference between the results pretest and post-test in the control class with the experimental class, although it can be seen in table that the control class has an increase in learning motivation however greater than increased learning motivation in the experimental class. This difference exists because the control class is not treated using learning Sparkol Videoscribe in fiqh subjects. However, for knowing the actual value can be calculated using SPSS 25 for Windows, with the following results: 
Table 4. Paired Samples T-Test of control class and experiment class in MAN 1 Kota Bogor

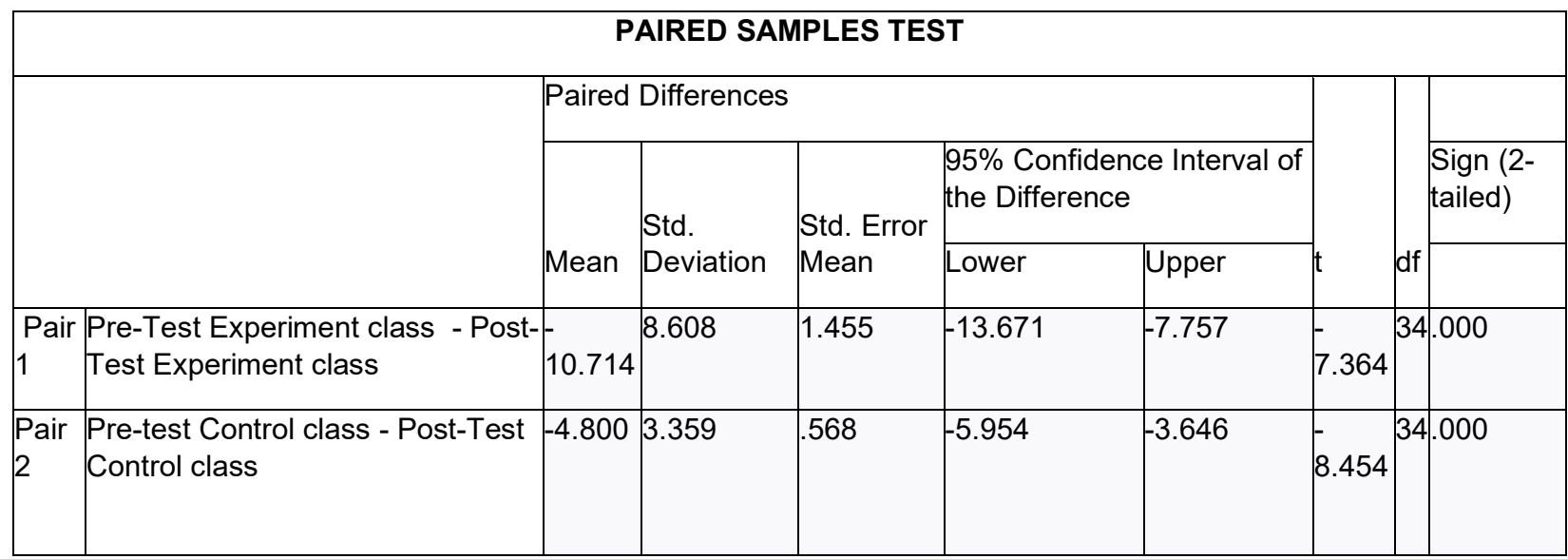

The calculation results in the increases in student motivation by using Sparkol table 6 regarding calculations of paired samples t- Videoscribe, with the average difference in the test in the control class and the experimental class can be seen that the average difference between the result pre-test and post-test in the control class is 4,800. sign minus (-) on its average rating are means the result post-test more than the result pre-test. On the other hand, the average differences of the experiment class marks the results pre-test and posttest of student learning motivation is 10,714. sign minus (-) indicates that the result of the post-test is greater than the result of pre-test. The results of the mean difference in the class show the difference before and after. This assessment can be seen defining an increases, but the bigger increase was in the experimental class. This means there is an control class and the experimental class amounting to 4,789 .

The calculation results in the control class is equal to 8,454 with a p-value of 0,000 sig (2-tailed), while the experimental class score " $t$ " of 7,364 with a p-value of 0,000 . Then it was decided that Ho was rejected and $\mathrm{Ha}$ was accepted. Then it can be concluded that there is a significant difference between the mean results of pre-tets and posttest. Statistically, it can be seen that the biggest difference is in the experimental class which is treated using learning media Sparkol Videoscribe on the eye fiqh lessons.

Table 5. Independent Samples T-Test Student's learning motivation in control class \& Experiment class MAN 1 Bogor

\begin{tabular}{|c|c|c|c|c|c|c|c|c|c|c|}
\hline \multicolumn{11}{|c|}{ Independent Samples Test } \\
\hline & & \multicolumn{2}{|c|}{$\begin{array}{l}\text { Levene's Test for } \\
\text { Equality of } \\
\text { Variances } \\
\end{array}$} & \multicolumn{7}{|c|}{ t-test for Equality of Means } \\
\hline & & \multirow[b]{2}{*}{$\mathrm{F}$} & \multirow[b]{2}{*}{ Sig. } & \multirow[b]{2}{*}{$t$} & \multirow[b]{2}{*}{ df } & \multirow{2}{*}{$\begin{array}{l}\text { Sig. (2- } \\
\text { tailed) }\end{array}$} & \multirow{2}{*}{$\begin{array}{l}\text { Mean } \\
\text { Difference }\end{array}$} & \multirow{2}{*}{$\begin{array}{l}\text { Std. Error } \\
\text { Difference }\end{array}$} & \multicolumn{2}{|c|}{$\begin{array}{l}95 \% \text { Confidence } \\
\text { Interval of the } \\
\text { Difference }\end{array}$} \\
\hline & & & & & & & & & Lower & Upper \\
\hline \multirow[t]{2}{*}{$\begin{array}{l}\text { Student's } \\
\text { learning } \\
\text { motivation }\end{array}$} & \begin{tabular}{|l} 
Equal \\
variances \\
assumed
\end{tabular} & 488 & .487 & 4.897 & 68 & .000 & 7.743 & 1.581 & 4.588 & 10.898 \\
\hline & \begin{tabular}{|l} 
Equal \\
variances not \\
assumed
\end{tabular} & & & 4.897 & 66.67 & 4.000 & 7.743 & 1.581 & 4.586 & 10.899 \\
\hline
\end{tabular}




\section{DISCUSSION}

In this study, the researcher held two meetings, field tests on July 1 - 13, 2020 both for the control class and the experimental class. Field tests of the control class and the experimental class were carried out to determine the effect of Sparkol Videoscribe media in increasing student learning motivation, using pre-test and post-test. The pretest was conducted to find out how motivated they were before using this developed media.

In the pre-test at the first meeting the teacher taught using conventional methods using lectures and media in the form of textbooks only. It turns out that there are still many students who chat with their classmates when the teacher explains the subject matter, and there are also students who are still joking. This shows that their learning motivation during the fiqh learning process is quite low. According Hamdu, G (2011) the motive encouragement in learning is one of the important aspects that need to be improved in overcoming learning in school.

According to Yulika, R (2019) learning motivation is a non-intellectual factor, has a function in increasing interest, feeling happy and enthusiastic in learning activities. The reason why students have low learning motivation during the learning process, one of which is because teachers less explore in using strategies, learning methods and learning resources.

The role of learning resources in the learning system is an important component between objectives, materials, methods and evaluation (Pamungkas, A. S., 2018: 129). One of the learning resources that can increase student motivation in the classroom is learning media. There is no need to pay expensive fees to use fun learning media, it is enough with the creativity of the teacher that learning media can be created and increase student learning motivation.

Sparkol Videoscribe is one of the media used as teaching material in learning activities at schools. Hasan A. A (2019: 145) stated that with its unique characteristics, Sparkol Videoscribe is able to provide learning content by combining images, audios and attractive designs so that students can enjoy the learning process. Likewise, when using the Sparkol Videoscribe in the experimental class, students when enthusiastic took lessons using the Q\&A method so that students played an active role during learning activities in the classroom.

It can be seen when using the media developed by the writers, some students showed an increasing level of interest when questioning with the images presented on the Sparkol Videoscribe. That they are very excited during learning activities and become more motivated. This shows that the Sparkol Videoscribe media as one of the learning medium for the fiqh subject that makes students focus and provides a good stimulus during learning activities.

This increase in learning motivation can be seen from the pre-test and post-test results of the questionnaire statements given to students. The experimental class showed a significant increase compared to the control class which was not given the use of Sparkol Videosribe media. This is in accordance with research conducted by Zulmiyetri (2019) which concluded that the results of the study conducted showed that Videoscribe was effective for improving reading fluency skills for students with learning disabilities.

The results of the normality test using the SPSS 25 for Windows in the pre-test and posttest of the experimental class were higher than the significance level, which is $0.071>0.05$ for pretest while for post-test is $0.200>0.05$. Meanwhile for the control class, the calculation of the normality test is obtained pre-test $0.200>0.05$ and posttest class control $0.200>0.05$. This means that the probability (Asymp. Sig (2-tailed)) of the experimental class and control class is higher than the significance level (0.05). In other words, the scores of the two groups were normally distributed. As for the homogeneity test obtained results (sig) base on mean amounting to $0.487>$ from 0,05 . It can be concluded that the data is homogeneous or with different variants same.

Based on the results of research carried out in this study in developing Sparkol 
Videoscribe media in fiqh subjects to increase learning motivation in class $\mathrm{X}$ students, it was found that class students and learning activities in MAN 1 Bogor City runs effectively even in online learning conditions, but students are more excited and motivated in learning by utilizing the learning media. Students understand better the practical activities ribawi as well as with more complete explanation of other material and including the practical examples of ribawi. This can be seen on the table 7 regarding the test independent samples ttest with the results of Sig (2-tailed) of $0.000<0,05$, thus $\mathrm{Ha}$ is accepted. This shows that there is a significant difference between class X MIPA 1 as the control class and class X MIPA 3 as the experimental class. Then it can it was concluded that there was an influence of learning media Sparkol Videoscribe on student learning motivation in fiqh subjects in MAN 1 Kota Bogor.

The results of this study indicate that the development of Sparkol Videoscribe media in the fiqh subject can increase student learning motivation in class X in MAN 1 Bogor City, with differences in learning motivation in the experimental class of 82.06, and in the control class of 74.31then the difference in the increase in learning motivation is 7.75. This research is in accordance with the research of Ana Sofiyah, et al (2018) with the conclusion that there is an increase in learning outcomes of Indonesian writing skills in elementary school students by $20 \%$.

\section{CONCLUSION}

The problem of learning fiqh at Madrasah lies in the material presented by the teacher. This is what makes students often less motivated during the learning process. Fiqh learning is a subject that discusses worship and muamalah. Fiqh is one of the scientific fields of Islamic sharia, which specifically discusses laws or regulations related to various aspects of human life, both concerning individuals, society, and human relations with Allah SWT. This knowledge needs to be supported by correct implementation in order to apply science in everyday life, so fiqh needs demonstration methods and media that able to describe the material. So the authors are interested in developing Sparkol Videoscribe media in the fiqh subject, with the subject of Riba, Bank and Insurance in describing activities related to these materials and able to increase student interest and motivation in learning activities in class. This media is flexible and efficient so that students can learn independently.

\section{REFERENCES}

Adam, S., \& Taufik, M. 2015. Pemanfaatan Media Pembelajaran Berbasis Teknologi Informasi Bagi Siswa Kelas X SMA Ananda Batam. CBIS Journal. 3(2). $78-90$.

Arikunto, Suharsimi. 2017. Dasar-dasar Evaluasi Pendidikan. Jakarta: Bumi Aksara.

Aryuntini, N., Astuti, I., Yuliana, Y. G. S. 2018. Development of Learning Media Based on VideoScribe to Improve Writing Skill for Descriptive Text of English Language Study. Journal of Education, Teaching and Learning. 3 (2). 187-194.

Bakar, R. 2014. The Effect Of Learning Motivation On Student's Productive Competencies In Vocational High School, West Sumatra. International Journal of Asian Social Science. 4(6): 722-732.

Chang, I. Y., \& Chang, W. Y. 2012. The Effect Of Student Learning Motivation On Learning Satisfaction. The International Journal of Organizational Innovation. 4 (3). 281-305.

Enita, P., Musthafa, A., Hasanah, R. 2019. MultimediaBased Learning Media Development. Proceeding International Seminar on Islamic Studies. 1 (1). 24-29.

Fitri, Y. 2020. The Effect of Learning Motivation and Visual Aids on Student Learning Achievement. International Journal of Research and Review. 7(1). 200-207.

Fujiyanto, Ahmad. 2016. Penggunaan Media Audio Visual Untuk Meningkatkan Hasil Belajar Siswa Pada Materi Hubungan Antarmakhluk Hidup. Jurnal Pena Ilmiah. Vol.1 No.1: 441-450.

Hamdi, Asep, Saepul, E. Bahruddin. 2014. Metode Penelitian Kuantitatif Aplikasi dalam Pendidikan. Yogyakarta: Deepublish.

Hamdu, G., Agustina, L. 2011. Pengaruh Motivasi Belajar Siswa Terhadap Pestasi Belajar Ipa Di Sekolah Dasar. Jurnal Penelitian Pendidikan. 12 (1). 90-96. 
Hamzah, A. 2019. Metode Penelitian \& Pengembangan. Malang: Literasi Nusantara.

Hannah, Nur 2016. Pengembangan Media CAI Mata Pelajaran Akidah Akhlak untuk Peserta Didik Kelas VII di MTs. Nurul Amanah Basanah Bangkalan (Tesis). Program Pasca Sarjana Universitas Islam Negeri Sunan Ampel Surabaya. https://digilib.uinsby.ac.id.

Hasan, A. A., Baroroh, U. 2019. Pengembangan Media Pembelajaran Bahasa Arab Melalui Aplikasi Videoscribe Dalam Meningkatkan Motivasi Belajar Siswa. Jurnal Lisanuna. 9 (2). 140-155.

Lin, M. H., Chen, H. C., Liu, K. S. 2017. A Study of the Effects of Digital Learning on Learning Motivation and Learning Outcome. EURASIA Journal of Mathematics Science and Technology Education. 13(7): 3553-3564.

Lumbantobing, P. A. 2020. The Contribution of Lecturer Pedagogical Competence, Intellectual Intelligence and Self-Efficacy of Student Learning Motivation. Budapest International Research and Critics in Linguistics and Education (BirLE) Journal. 3 (1). 564-573.

Lutfiah, Via Laila, Maemunah Sa'diyah. 2019. Peningkatan Motivasi Belajar Dengan Menerapkan Strategi Pembelajaran Everyone Is A Teacher Here Pada Mata Pelajaran Pai Di SMAN 2 Bogor. Jurnal Mitra Pendiidkan (JMP Online). Vol. 3 No. 4: 496-506.

Maulina, U., Hikmah, S., \& Pahamzah, J. 2019. Attractive Learning Media to Cope with Students' Speaking Skills in the Industry 4.0 Using Sparkol Videoscribe. International Journal of Linguistics, Literature and Translation (IJLLT). 2 (5). 132-140.

Pamungkas, A. S., Ihsanudin, Novaliyosi, \& Yandari, I. A. V. 2018. Video Pembelajaran Berbasis Sparkol Videoscribe: Inovasi Pada Perkuliahan Sejarah Matematika. Prima: Jurnal Pendidikan Matematika. 127-135.

Pohan, A. M., Asmin, Menanti A., 2020. The Effect of Problem Based Learning and Learning Motivation of Mathematical Problem Solving Skills of Class 5 Students at SDN 0407 Mondang. Budapest International Research and Critics in Linguistics and Education (BirLE) Journal. 3(1). 531-539.

Qolbi, M. S., At Thaariq, Z. Z., Az-Zahroh, S. F., Anwar, M. M., Faiza N. 2019. Design and Development of Game Based Learning Applications for Mathematics Learning Based on Multiple Language to Develop Verbal Capabilities. Jurnal Pendidikan dan Pembelajaran. 26 (2), 51-56.

Radyuli, P, Wijaya I, Ulfina, I. 2020. Correlation of SelfConfidence and Student Learning Motivation Against Learning Outcomes of Class X Digital Simulation. Journal of Educational Research and Evaluation. 4 (2). 216-220.

Riduwan. 2012. Skala Pengukuran Variabel-variabel Penelitian. Bandung: Alfabeta.

Sardiman. 2016. Interaksi \& Motivasi Belajar Mengajar. Jakarta: PT. RajaGrafindo Persada.

Sa'diyah, M. 2019. Kontektualisasi Pendidikan Agama Islam Dalam Pembelajaran Berkebun Vertikal Berbasis Madrasah. Attadib Journal Of Elementary Education. 3 (2). 1-16.

Sahronih, S., Purwanto. A..\& Sumantri. M.S. 2020. The effect of Use Interactive Learning Media Environment-based and Learning Motivation on Science Learning Outcomes. International Journal for Educational and Vocational Studies. 2(3). 1-5.

Sofiya, A., Yulianto, B., \& Hendratno. 2018. The Development of Sparkol Videoscribe Based Internet Learning Media in Improving Writing Skills of Indonesian Language for Elementary School Students. Atlantis Press 2nd International Conference on Education Innovation. 212. 108-111.

Sofyan, A., Rafiudin, Soraya, R. A. 2019. The Development of Learning Media Using Sparkol Videoscribe Software on Natural Science Education Subjects. Atlantis Press International Conference on Education Technology. 372. 1621.

Sudijono, Anas. 2015. Pengantar Statistik Pendidikan. Jakarta: PT. RajaGrafindo Persada.

Sugiyono. 2017. Metode Penelitian Pendidikan Pendekatan Kuantitatif, Kualitatif, dan R\&D. Bandung: ALFABETA.

Sukmadinata, Nana Syaodih. 2017. Metode Penelitian Pendidikan. Bandung: PT. Remaja Rosdakarya.

Syakur, A., Sugirin, \& Widiarni. 2020. The Effectiveness of English Learning Media through Google Classroom in Higher Education. Britain International of Linguistics, Arts and Education (BIoLAE). 2(1). 475-483. 
Utami, P. R. A., Santyasa, I., Rapi, N. K. 2018. The Relationship Between Learning Motivation And Emotional Intelligence With Physics Learning Achievement Of Public High School Students Class XI MIA In Singaraja City. Jurnal Pendidikan Dan Pembelajaran.25(1). 25-33.

Wulandari, D. A. 2016. Skripsi Pengembangan Media Pembelajaran Menggunakan Sparkol Videoscribe Dalam Meningkatkan Minat Belajar Siswa Pada Mata Pelajaran Ipa Materi
Cahaya Kelas VIII Di Smp Negeri 01 Kerjo Tahun Ajaran 2015/ 2016. Universitas Negeri Semarang. https://lib.unnes.ac.id/24181/1/1102412106.pdf

Zulmiyetri, Kasiyati, Kusumastuti, G. 2019. Improving Reading Fluency Through Videoscribe for Student with Learning Disability. International Journal of Research in Counseling and Education. 03 (2). 76-81. 